\title{
Super-deep diamonds from kimberlites in the Juina area, Mato Grosso State, Brazil
}

\author{
Felix V. Kaminsky ${ }^{1,3}$, Galina K. Khachatryan ${ }^{1}$, Paulo Andreazza ${ }^{2}$, \\ Debora Araujo ${ }^{3}$, William L. Griffin ${ }^{3}$ \\ ${ }^{1}$ KM Diamond Exploration Ltd., West Vancouver, Canada \\ ${ }^{2}$ Diagem do Brasil Mineração Ltda., Brazil \\ ${ }^{3}$ GEMOC Key Centre, Dept. of Earth and Planetary Sciences, Macquarie University, Sydney, \\ Australia
}

In the last decade, the study of diamonds from the placer deposits of the Juina area, Mato Grosso State, Brazil has provided important information on the composition and origin of the deepest accessible levels of the Earth's lithosphere and lower mantle (Harte et al., 1999; Kaminsky et al., 2001; Hayman et al., 2005). In 2006-2007, a group of kimberlitic pipes was discovered by Diagem in the Chapadão area. They form a new kimberlite cluster containing high-grade $\left(0.2-1.8 \mathrm{ct} / \mathrm{m}^{3}\right)$ volcaniclastic layers. Diamondiferous layers, considered a primary kimberlitic ash-fall, were bulk-sampled, and representative quantities of diamonds were gained.

\section{Diamond morphology and coloration}

Diamonds from the Juina kimberlitic pipes, like ones from previously studied Juina placer deposits, are very homogeneous in their morphology and optical properties. There are only two major crystallographic forms in these crystals, dodecahedral (from $27.8 \%$ to $41.8 \%$ of the stones) and octahedral (from $9.3 \%$ to $12.7 \%$ in Pandrea pipes, and from $5.0 \%$ to $6.6 \%$ in pipes Aripuana- 1 and Collier-4 respectively). A very limited variety of face accessories is present on the stones. No cubic crystals or even cubic faces were found among the diamonds studied. The diamonds from the Juina kimberlitic pipes are colourless, grey/ greyish, brown/ brownish, and yellow/ yellowish. In some cases, the smoky-brown colour of the diamonds is due to plastic deformation, while the yellow colour is caused by a nitrogen impurity in the diamond. Grey colouration is caused by the presence of numerous small black graphite-like inclusions.

\section{Infrared spectroscopy of diamonds}

The diamonds from the Juina pipes, like those from the placer deposits, are substantially different in their nitrogen impurity characteristics from most other kimberlite-related diamonds. In the Pandrea pipes, 25$56 \%$ of diamonds are 'nitrogen-free'. Type IaBdiamonds comprise $40-65 \%$ of all studied pipe diamonds. The diamonds form two populations: a major population with a highly aggregated nitrogen impurity (\% $\left.\mathrm{N}_{\mathrm{B}}=75-100 \%\right)$, and a secondary population with a moderately aggregated nitrogen impurity $\left(\% \mathrm{~N}_{\mathrm{B}}=20-65 \%\right)$. The total nitrogen contents in both diamond populations are the same (Fig. 1).

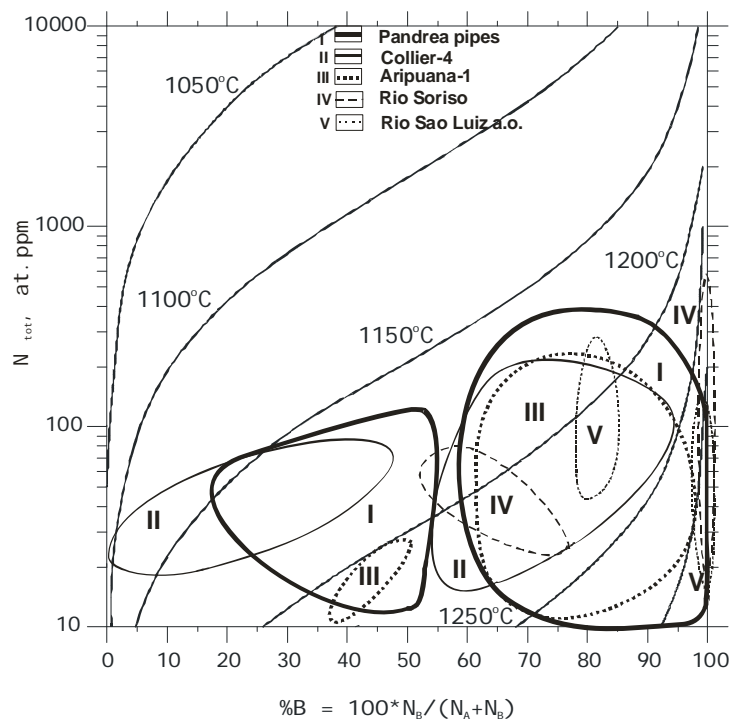

Fig. 1. Distribution of total nitrogen content against proportion of aggregated nitrogen in diamonds from the pipes and placer deposits (Rio Soroso, Rio Sao Luiz, a.o.) in the Juina area. Isotherm curves for $3 \mathrm{Ga}$ after Taylor and Milledge (1995).

In contrast to most diamond deposits worldwide, almost all diamonds from the Juina pipes (80-89 \%) have noticeable (up to $4.2 \mathrm{~cm}^{-1}$ ) levels of hydrogen $\mathrm{H}$ centres.

\section{Mineral inclusions in diamonds}

Ferropericlase, chrome spinel, picroilmenite, Mnilmenite, a MgCaSi-perovskite phase, rutile, sulphides, and native iron were identified among inclusions in Juina pipe diamonds. Some of them form associations: ferropericlase + spinel + native Fe, chrome spinel + MgCaSi-perovskite, and picroilmenite + Mn-ilmenite. 
Ferropericlase is the most abundant mineral inclusion in the diamonds studied, as in other Juina diamonds. It has a range of $\mathrm{mg}$ from 0.518 to 0.810 , within the wider range defined by other ferropericlase compositions from the Juina placer deposits (0.380.85). The major impurities are Ni (0.59-1.48 wt.\% $\mathrm{NiO}), \mathrm{Cr}\left(0.09-0.65\right.$ wt.\% $\left.\mathrm{Cr}_{2} \mathrm{O}_{3}\right)$, Mn (0.14-0.73 wt.\% $\mathrm{MnO})$, Na (0.01-0.72 wt.\% $\left.\mathrm{Na}_{2} \mathrm{O}\right)$, and $\mathrm{Zn}(0.02-0.10$ wt.\% $\mathrm{ZnO})$.

Chrome spinel is the second most common inclusion phase. Compositionally it differs drastically from spinel identified in placer diamonds. In contrast to titaniferous chrome spinel with $10-11$ wt. $\% \mathrm{TiO}_{2}$ from placer diamonds, the studied grains have only 0.12 0.58 wt. $\% \mathrm{TiO}_{2}$ and cannot be called 'titaniferous'. The $\mathrm{Fe}_{\text {tot }}$ content in the studied spinel grains is also lower $(\mathrm{FeO}=14.11-22.29$ wt.\% against $35-37$ wt.\% in the earlier-studied inclusions from placer deposits). Al and Cr concentrations in the studied grains are significantly higher: $\mathrm{Al}_{2} \mathrm{O}_{3}=12.85-19.75$ wt. $\%$, and $\mathrm{Cr}_{2} \mathrm{O}_{3}=45.93-$ 58.16 wt. $\%$ against 5-6 \% and 35-37 \%, respectively, in 'placer' inclusions. The $\mathrm{mg}$ of the studied spinel inclusions is generally higher: 0.347-0.558 against 0.35-0.36. The compositions of the studied chrome spinel inclusions within a single diamond vary in both Cr content (by several per cent) and $m g$ ( $\Delta=0.07$ 0.14). In newly studied chrome-spinel grains, concentrations of $\mathrm{Ti}, \mathrm{V}, \mathrm{Cu}, \mathrm{Zr}$, and $\mathrm{Nb}$ are two orders of magnitude lower, while Co and $\mathrm{Zn}$ are significantly higher than in the titaniferous spinels from the placer diamonds (Fig. 2).

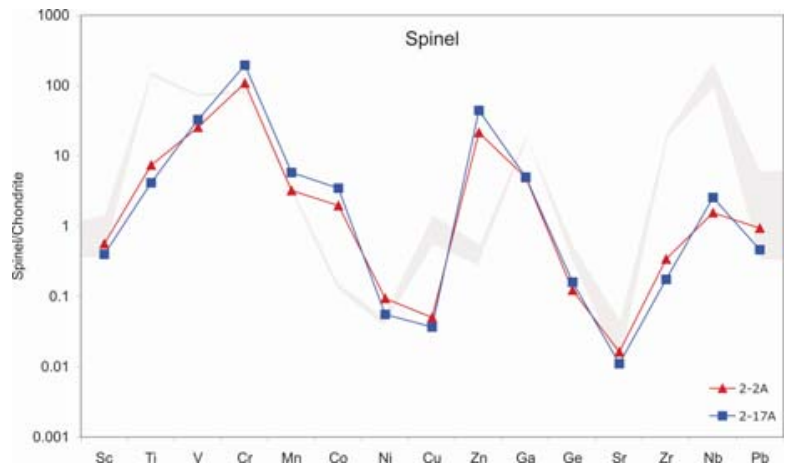

Fig. 2. Chondrite-normalized trace element distribution in chrome spinel inclusions in Juina kimberlitic diamonds. Shaded area - trace element distribution in spinel from Juina placer diamonds [after Kaminsky et al., 2001].

Two grains of MgCaSi-perovskite were identified in a single diamond from pipe Pandrea-2. The chemical composition of this mineral has not been reported before. The $m g$ numbers of these grains are extremely high (0.966 and 0.969); the highest reported value even for MgSi-perovskite from all areas with lower-mantle diamonds. The average formula for two grains is as following: $\mathrm{Mg}_{1.2} \mathrm{Fe}_{0.03} \mathrm{Ca}_{0.6} \mathrm{Al}_{0.04} \mathrm{Si}_{2.05} \mathrm{O}_{6}$. Since the grain is opaque, and the two analyses show a spread, especially in $\mathrm{Al}$ and $\mathrm{Ca}$, it is possible that the grains were originally a mixture of Mg- and Ca-perovskites, and are now a fine-grained mixture due to decompression breakdown.

Rutile is recorded as a mineral inclusion in Juina diamonds (as well as in the ultra-deep association worldwide) for the first time. It has a low concentration of $\mathrm{FeO}$, compared to other rutile grains included in diamond, 0.21-0.44 wt\% FeO, while rutile included in diamond typically has 1.3-1.8 wt\% (Sobolev, 1974). The studied rutile grains have also low Cr contents (0.09-0.13 wt\%); they belong to the eclogitic association. There are also minor admixtures of $\mathrm{Al}$ and $\mathrm{V}$ in the studied grains. Low totals (91.6-98.5 \%) suggest the presence of other elements.

Native iron has significant contents of $\mathrm{Cr}_{2} \mathrm{O}_{3}$ (2.37 wt.\%), $\mathrm{NiO}$ (0.40 wt.\%), $\mathrm{MgO}$ (0.94 wt.\%), and $\mathrm{MnO}$ (0.17 wt.\%).

The sulphide grains are composed mainly of iron and sulphur, with a small admixture of $\mathrm{Cu}$ (0.39-0.80 wt. $\%)$ and minor amounts of $\mathrm{Ni}$ (0.02-0.06 wt.\%), and may be attributed to the eclogitic paragenesis. One of the grains has small (3-10 $\mu \mathrm{m}$ long) lamellae which are very rich not only in $\mathrm{Ni}$ (22.2 wt.\%) but in Co (14.19 wt.\%).

\section{Carbon isotopic composition of diamonds}

The isotopic composition of carbon in most diamonds from the Pandrea pipes ranges from $-2.67 \%$ to -7.46 $\%$, i.e., it is almost exactly the same as for the previously studied placer diamonds (Kaminsky et al., 2001). $6.5 \%$ diamonds have a 'light' (<-9\%) isotopic composition (Fig. 3). Three of the 'light' diamonds have mineral inclusions of the eclogitic paragenesis (rutile and sulphide); this suggests that the other isotopically 'light' diamonds are also of the eclogitic paragenesis.

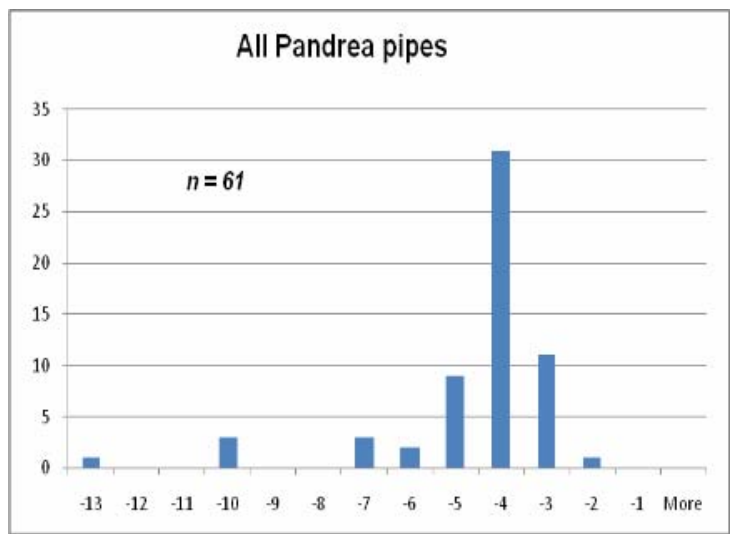

Fig. 3. Carbon isotopic composition of diamonds (in \%o $\delta^{13} \mathrm{C}$ ) from Pandrea pipes. 


\section{Discussion and conclusions}

All Juina diamonds (both kimberlitic and placer) revealed the features that are different to diamonds from other regions. Firstly, there are high proportions of nitrogen-free and low-nitrogen crystals amongst the Juina diamonds. Secondly, the high proportion of IaB diamonds among the nitrogen-containing crystals suggests that they had a prolonged thermal history, which resulted in the almost complete transformation of single-atomic and paired nitrogen centres into polyatomic complexes. Probably, the crystallization and later annealing of Juina diamonds occurred at high temperatures.

A study of mineral inclusions in diamonds from the Juina pipes reveals that they have the same mineral assemblage as previously studied samples from Juina placer deposits (Harte et al., 1999; Kaminsky et al., 2001; Hayman et al., 2005). Most of the inclusions belong to the lower-mantle paragenesis; however some (rutile and sulphide) are of eclogitic paragenesis. Besides, $6.5 \%$ of the studied diamonds have a 'light' (<-9\%o), 'eclogitic' isotopic composition. This agrees with the identification of carbonates and nanometresized crystals of a hydrous aluminium silicate phase (so-called 'phase Egg', $\mathrm{AlSiO}_{3}(\mathrm{OH})$ ), in other Juina diamonds (Brenker et al., 2007; Wirth et al., 2007). These data may be considered as proofs that formation of diamondiferous kimberlites in Juina has been initiated by the subduction of crustal material to the depth of the transition zone and lower mantle.

By a complex of characteristics (morphology, mineral inclusions, IR spectra, and carbon isotopic composition) diamonds from the Juina pipes and placer deposits are similar to each other. Diamonds from both groups, kimberlites and placer deposits, belong to the same genetic population with most of the stones originating within the superdeep (lower-mantle and transition zone) conditions.

However, there are some quantitative differences between the placer diamonds and the pipe diamonds. (1) The number of octahedral diamonds is $2-3$ times higher in the Pandrea pipes than in the previously studied placer deposits. The average D/Oct ratio for the Pandrea pipes is 2.9 against 13.1 in placer deposits. (2) Two diamond populations exist in the Pandrea pipes: the major population with a highly aggregated nitrogen impurity, and a secondary population with a moderately aggregated nitrogen impurity, while only one major population is present in the diamonds from placers; and in diamonds from placer deposits type IaB-diamonds are strongly, by several times, predominate over type II-diamonds, while in the Pandrea diamonds the ratio of these groups is almost even. (3) Mineral inclusions in diamonds from kimberlitic pipes appeared to be different in composition than the same minerals in placer diamonds. Some of these differences are minor, however, other differences are substantial, such as the differences in spinel compositions: instead of 'titaniferous' spinel inclusions in placer diamonds, there are chrome spinel inclusions in pipe diamonds. (4) Both kimberlitic and placer diamonds belong to the same population, but have differences in the $\delta^{13} \mathrm{C}$ distribution, and were probably formed from different local carbon sources. These data indicate that besides the discovered Pandrea pipes which may have at least partly supplied diamonds to the studied earlier placer deposits, there may be other, still unknown primary sources of diamonds in the Juina area.

\section{References}

Brenker, F.E., Vollmer, C., Vincze, L., Vekemans, B., Szymanski, A., Janssens, K., Szaloki, I., Nasdala, L., Kaminsky, F., 2007. Carbonates from the lower part of transition zone or even the lower mantle. Earth and Planetary Science Letters 260 (1-2), 1-9.

Harte, B., Harris, J.W., Hutchison, M.T., Watt, G.R., Wilding, M.C., 1999. Lower mantle mineral associations in diamonds from Sao Luiz, Brazil. In: Fei, Y., Bertka, C.M., Mysen, B.O. (Eds), Mantle Petrology: Field Observations and High Pressure Experimentation. Geochemical Society Special Publication 6, 125-153.

Hayman, P.C., Kopylova, M.G., Kaminsky, F.V., 2005. Lower mantle diamonds from Rio Soriso (Juina, Brazil). Contributions to Mineralogy and Petrology 149 (4), 430-445.

Kaminsky, F.V., Zakharchenko, O.D., Davies, R., Griffin, W.L., Khachatryan-Blinova, G.K., Shiryaev, A.A., 2001. Superdeep diamonds from the Juina area, Mato Grosso State, Brazil. Contributions to Mineralogy and Petrology 140 (6), 734-753.

Sobolev, N.V., 1974. Deep-seated inclusions in kimberlites and the problem of the composition of the upper mantle. Nauka Press, Novosibirsk, 264 p. (in Russian). English Translation (1977), ed. by F.R. Boyd, American Geophysical Union, Washington, D.C., 279 $\mathrm{p}$

Taylor, W.R., Milledge H.J., 1995. Nitrogen aggregation character, thermal history and stable isotope composition of some xenolith-derived diamonds from Roberts Victor and Finch. In: Sixth Internat. Kimberlite Conf. Extended Abstr., Novosibirsk, August 1995, 620622.

Wirth, R., Vollmer, C., Brenker, F., Matsyuk, S., Kaminsky, F., 2007. Nanocrystalline hydrous aluminium silicate in superdeep diamonds from Juina (Mato Grosso State, Brazil). Earth and Planetary Science Letters 259 (3-4), 384-399. 